\title{
ANALISIS KINERJA PEMUNGUTAN DAN RETRIBUSI PAJAK REKLAME TERHADAP PENDAPATAN ASLI DAERAH (PAD) KOTA BATAM
}

\author{
Syahril Effendi ${ }^{1,}$ Neni Marlina Br Purba ${ }^{2}$ \\ Dosen program Studi Akuntansi, Universitas Putera Batam \\ email: syahril@puterabatam.ac.id
}

\begin{abstract}
This study aims to find answers to the performance level of billboard tax collection in Batam City, and its contribution to local tax revenues in Batam City. This research applies descriptive analysis method, where this method is used to provide systematic explanations, actual and accurate statements of facts, and only describe situations or events not to find or explain relationships and test hypotheses. The object of this research is the Batam City Dispenda. The sampling technique used is non probability sampling, namely the technique of determining the sample using certain considerations or in (purposive sampling) using financial statements from 2011 to 2015. The results of the hypothesis test show that simultaneous performance of collection and levy on advertisement tax collection in the Dispenda Batam City has a significant effect on local revenue. While partially the collection performance at the Batam City Dispenda has a significant relationship to local original income, however, advertisement tax collection levies have a significant influence on local revenue in Batam City Dispenda.
\end{abstract}

Keywords: Collecting performance, Levy Levy advertisement tax, revenue.

\section{PENDAHULUAN}

Pajak merupakan salah satu sumber penerimaan utama bagi sebuah negara yang dibayarkan oleh masyarakat. Pajak juga sebagai iuran pemungutan yang dapat dipaksakan oleh pemerintah berdasarkan ketentuan peraturan perundang-undangan perpajakan serta sebagai perwujudan peran serta masyarakat atau wajib pajak untuk secara langsung dan bersama-sama melaksanakan kewajiban perpajakan yang diperlukan untuk pembiayaan negara dan pembangunan nasional.

Tujuan pembangunan nasional adalah untuk mewujudkan masyarakat yang adil dan makmur melalui peningkatan taraf hidup, kecerdasan dan kesejahteraan seluruh rakyat. Dalam pelaksanaan pembangunan nasional tersebut tidak terlepas oleh adanya pembangunan daerah. Sehingga untuk memperlancar pembangunan nasional diperlukan anggaran dari pemerintah negara yang diperoleh dari pemungutan pajak daerah. Untuk itulah pemerintah terus berupaya menggali setiap potensi yang bisa digunakan untuk meningkatkan dan mengoptimalkan penerimaan daerah. Otonomi daerah merupakan suatu konsekuensi reformasi yang harus dihadapi oleh seluruh daerah di Indonesia. Oleh karena itu, dibutuhkan pembelajaran di setiap daerah untuk dapat mengubah tantangan menjadi sebuah peluang bagi kemajuan daerahnya. Disisi lain, pemerintah sebagai pengatur pengembangan konsep otonomi daerah, berperan sebagai penanggung jawab agar konsep otonomi daerah dapat dilaksanakan seperti yang diharapkan.

Adanya Undang-undang Nomor 28 Tahun 2009 tentang Pajak Daerah dan Retribusi Daerah dan Peraturan Daerah Kota Batam Nomor 12 Tahun 2008 tentang pokok-pokok pengelolaan keuangan daerah, membawa paradigma baru dalam pengelolaan daerah, dimana daerah diberikan kewenangan untuk mengelola sendiri kegiatannya yang meliputi: perencanaan, pelaksanaan, penatausahaan, pelaporan, pertanggungjawaban, dan pengawasan keuangan daerah. Atau dengan kata lain, daerah berhak mengatur sumber daya daerahnya untuk pencapaian perencanaan yang diharapkan. Dimana otonomi daerah memiliki peran sebagai 
upaya pemberdayaan daerah untuk mengambil keputusan sesuai dengan potensi dan kepentingan daerah itu sendiri.

Sehingga untuk melaksanakan otonomi daerah, pemerintah harus dapat mengidentifikasi sektor-sektor yang dinilai potensial sebagai pendorong pembangunan daerah, terutama melalui upaya peningkatan potensi Pendapatan Asli Daerah (PAD). Dimana kemampuan daerah dalam memaksimalkan Pendapatan Asli Daerah (PAD) dapat dilakukan melalui peran serta masyarakat dalam pembayaran pajak dan retribusi. Tanggungjawab atas kewajiban pelaksanaan pemungutan pajak daerah berada pada seluruh wajib pajak. Sedangkan pemerintah sebagai aparatur, berkewajiban memberikan pembinaan, pelayanan dan pengawasan terhadap seluruh pemenuhan kewajiban perpajakankepada wajib pajak.

Seiring dengan bergulirnya otonomi daerah, telah merubah paradigma penyelenggaraan pemerintahan di daerah dimana kekuasaan yang bersifat sentralistik berubah menjadi desentralistik dengan memberikan otonomi yang seluas-luasnya sebagaimana diatur dalam Undang-undang Nomor 22 Tahun 1999 tentang Pemerintahan Daerah selanjutnya disingkat dengan sebutan UU No. 22/1999, kemudian diganti dengan Undang-undang Nomor 32 Tahun 2004 selanjutnya disingkat dengan sebutan UU No. 32/ 2004. Perubahan kebijakan pengaturan pemerintahan daerah tersebut diselaraskan dengan adanya perubahan kebijakan terhadap pajak dan retribusi daerah sebagai landasan bagi daerah dalam menggali potensi pendapatan daerah khususnya pendapatan asli daerah, yakni Undang-undang Nomor 18 Tahun 1987 tentang Pajak Daerah dan Retribusi Daerah selanjutnya disingkat dengan sebutan UU No. 18/1987, kemudian dirubah dengan Undang-undang Nomor 34 Tahun 2000 tentang Perubahan Atas Undangundang Nomor 18 Tahun 1987 tentang Pajak Daerah dan Retribusi Daerah, selanjutnya disingkat dengan sebutan UU No. 34/2000.

Perubahan berbagai kebijakan nasional sebagaimana dimaksud membawa harapan besar bagi daerah untuk membangun daerahnya dengan menggali potensi daerahnya masing-masing sebagai sumber pendapatan daerah, khususnya pendapatan asli daerah. Harapan dari daerah tersebut merupakan hal yang wajar, karena diberikannya berbagai urusan pemerintahan sebagai urusan rumah tangganya dibarengi dengan muatan kewenangan untuk mengurus keuangannya secara otonom dalam membiayai penyelenggaraan otonomi, baik dalam menggali sumbersumber keuangan, pemanfaatannya serta pertanggungjawabannya.

Pendapatan Asli Daerah sebagai sumber pendapatan dalam pembiayaan pembangunan perlu dikelola dengan baik, yang dalam hal ini dibutuhkan berbagai kebijakan yang lebih komprehensif, efektif dalam pengelolaannya. Undang-undang Nomor 32 tahun 2004 tentang pemerintahan daerah dan Undang undang Nomor 33 tahun 2004 tentang perimbangan keuangan antara pemerintah pusat dan pemerintah daerah. Hal ini memberikan dampak yang luas terhadap perkembangan pemerintahan di daerah. Otonomi yang diberikan kepada daerah merupakan otonomi yang luas, nyata dan bertanggung jawab. Adanya pemberian otonomi daerah memberikan implementasi timbulnya kewenangan dan kewajiban daerah untuk melaksanakan berbagai kegiatan pemerintahan yang lebih mandiri.

Kunci kemandirian daerah adalah pengelolaan Pendapatan Asli Daerah (PAD). Pajak daerah sebagai salah satu sumber Pendapatan Asli Daerah (PAD) diharapkan mampu memberikan kontribusi yang besar bagi daerah itu sendiri sehingga dapat memperlancar penyelenggaraan pemerintah dan pembangunan daerah. Sedangkan kemampuan keuangan daerah diukur dari besarnya kontribusi Pendapatan Asli Daerah (PAD) terhadap anggaran pendapatan daerah, dimana salah satu caranya yaitu dengan mengoptimalkan pajak daerah yang sudah ada.

Sebagai salah satu daerah otonom, Batam sudah seharusnya melaksanakan programprogram pembangunan baik program jangka pendek maupun jangka panjang. Untuk merealisasikan program pembangunan tersebut, pemerintah kota Batam berusaha untuk mengoptimalkan pendapatan daerah melalui pajak reklame. Karena apabila dilihat dari kontribusinya bagi pajak daerah, pajak reklame sebagai salah satu sumber Pendapatan Daerah yang berpotensi, dan dapat dilakukan pemungutan secara efisien, efektif, dan ekonomis sehingga dapat lebih berperan dalam usaha peningkatan Pendapatan Asli Daerah khususnya di 
Kota Batam. Kekuatan APBD paling besar diperoleh dari potensi pajak daerah yang dapat terus ditingkatkan setiap tahunnya. Berlakunya Undang-undang No. 28 Tahun 2009 tentang Pajak Daerah dan Retribusi Daerah menjadi salah satu penyebab rendahnya pendapatan dari sektor pajak di Kota Batam.

Hingga akhir tahun anggaran 2015, perolehan pajak jauh dari yang diharapkan, dan salah satunya perolehan dari pajak reklame yang pendapatannya menurun drastis hingga 30 persen dari target awal. Disamping itu, pemerintah kota juga takut untuk membongkar paksa tiang dan papan reklame yang belum membayar pajak. Yang alasannya, masalah hukum dikemudian hari.

Banyaknya reklame yang tidak membayar pajak merupakan reklame yang berada didaerah milik jalan (damija) dan taman. Dimana reklame tersebut pungutan sewanya sulit ditarik dan banyak yang perizinannya sudah mati, namun masih berdiri tegak tanpa adanya tindakan dari pemerintah kota. Evaluasi perolehan pajak reklame pada Kota Batam hingga akhir tahun 2015 membuktikan persentasase pencapaiannya masih rendah, dan dinilai tidak memenuhi target perencanaan Pemerintah Kota. Dimana target pendapatan di awal APBD tahun anggaran 2015, antara realisasi dan pencapaiannya tidak sebanding.

Perolehan Pendapatan Asli Daerah (PAD) Kota Batam dari sektor pajak reklame ini memiliki potensi tinggi, karena tidak sedikit perorangan atau badan usaha yang menggunakan reklame sebagai alat untuk mempromosikan usahanya. Selain itu dalam pemungutan pajak reklame seharusnya tidak sulit, karena objek dan jumlah titiknya sudah jelas. Seharusnya pencapaian perolehan Pendapatan Asli Daerah (PAD) dari sektor ini dapat terpenuhi. Sehingga dengan mengoptimalkan kinerja pemungutan dari pajak reklame diharapkan dapat meningkatkan Pendapatan Asli Daerah (PAD) Kota Batam.

Berdasarkan penjabaran diatas maka rumusan masalah adalah Seberapa besar Pengaruh Kinerja Pemungutan Dan Retribusi Pungutan Pajak Reklame Terhadap Pendapatan Asli Daerah (PAD) Kota Batam baik secara pasrsial maupun secara simultan. Tujuan penelitian adalah Untuk mengetahui Pengaruh Kinerja Pemungutan Dan Retribusi Pungutan Pajak Reklame Terhadap Pendapatan Asli Daerah (PAD) Kota Batam. baik secara pasrsial maupun secara simultan.

\section{TINJAUAN PUSTAKA}

\section{Kinerja Pemungutan}

Kinerja pemungutan pajak reklame di Indonesia saat ini didasarkan pada dasar hukum yang jelas dan kuat sehingga harus dipatuhi oleh masyarakat dan pihak terkait. Dasar hukum pemungutan pajak reklame pada suatu kabupaten/kota menurut Siahaan (2015: 325) adalah:

1. Undang-undang Nomor 34 Tahun 2000 yang merupakan perubahan atas Undangundang Nomor 18 Tahun 1997 tentang Pajak Daerah dan Retribusi Daerah.

2. Peraturan Pemerintah Nomor 65 Tahun 2001 tentang Pajak Daerah

3. Peraturan Daerah kabupaten/ kota yang mengatur tentang Pajak Reklame.

4. Keputusan bupati/walikota yang mengatur tentang Pajak Reklame sebagai aturan pelaksanaan peraturan daerah tentang Pajak Reklame pada kabupaten/kota dimaksud.

Agar kinerja pemungutan pajak tidak menimbulkan hambatan atau perlawanan, maka pemungutan pajak harus memenuhi syarat (Mardiasmo, 2013: 2-3) sebagai berikut.

1. Pemungutan pajak harus adil (Syarat Keadilan)

Sesuai dengan tujuan hukum, yakni mencapai keadilan, undang-undang dan pelaksanaan pemungutan harus adil. Adil dalam perundang-undangan diantaranya mengenakan pajak secara umum dan merata, serta disesuaikan dengan kemampuan masing-masing. Sedangkan adil dalam pelaksanaannya yakni dengan memberikan hak bagi Wajib Pajak untuk mengajukan keberatan, penundaan dalam pembayaran dan mengajukan banding kepada Majelis Pertimbangan Pajak.

2. Pemungutan pajak harus berdasarkan undang-undang (Syarat Yuridis)

Di Indonesia, pajak diatur dalam UUD 1945 pasal 23 ayat 2. Hal ini memberikan jaminan hukum untuk menyatakan keadilan, baik bagi negara maupun warganya. 
3. Tidak mengganggu perekonomian (Syarat Ekonomis)

Pemungutan tidak boleh mengganggu kelancaran kegiatan produksi maupun perdagangan, sehingga tidak menimbulkan kelesuan perekonomian masyarakat.

4. Pemungutan pajak harus efisien (Syarat Finansial)

Sesuai fungsi budgetair, biaya pemungutan pajak harus dapat ditekan sehingga lebih rendah dari hasil pemungutannya.

5. Sistem pemungutan pajak harus sederhana

Sistem pemungutan yang sederhana akan memudahkan dan mendorong masyarakat dalam memenuhi kewajiban perpajakannya. Syarat ini telah dipenuhi oleh undangundang perpajakan yang baru.

\section{Retribusi Pungutan Pajak Reklame}

Retribusi reklame merupakan salah satu Pendapatan Asli Daerah (PAD) Kota Batam dikelola oleh Dinas Pendapatan Daerah (PAD) Kota Batam. Pembangunan yang ada di Kota Batam merupakan tanggung jawab seluruh pihak Pemerintah, para pengusaha dan masyarkat yang membrikan dukungan kelancaran pembangunan tersebut.

Retribusi reklame dikenakan per tahun (1 Tahun), kecuali retribusi untuk jenis umbulumbul dikenakan per minggu (1 minggu), Perwako Pemerintah Kota Batam Nomor 24 Tahun 2011, Retribusi Ijin Penyelenggaraan Reklame adalah pungutan daerah sebagai pembayaran atas jasa pelayanan terhadap ijin pemasangan reklame di luar sarana prasarana kota.

Dalam pelaksanaan pemungutan retribusi reklame oleh Dinas Pendapatan Asli Daerah Kota Batam, yang mana telah ditentukan Peraturan Daerah Kota Batam (Perda) Nomor 5 Tahun 2009 tentang Retribusi Penggunaan Tanah dan/atau Bangunan Yang Dikuasai Pemerintah Daerah Untuk Pemasangan Reklame dalam Bab IV tentang Nama, Obyek, Subyek, dan Wajib Retribusi Pasal 6 yang berbunyi setiap orang dan/atau Badan Hukum yang menggunakan pemakaian tanah dan/atau bangunan yang dimiliki atau dikuasai oleh Pemerintah Daerah untuk pemsangan reklame dipungut retribusi dengan nama retribusi penggunaan tanah dan/atau bangunan yang dimiliki atau dikuasai oleh Pemerintah Daerah untuk pemasangan reklame. Dalam penentuan harga yang telah ditentukan dalam Peraturan Walikota Kota Batam Nomor 24 Tahun 2011 terbagi menjadi beberapa kategori kelas / kawasan yaitu 3 kelas / kawasan kategori:

Tabel 1. Kawasan

\begin{tabular}{|c|c|l|}
\hline No & Kelompok & Kawasan \\
1 & $\begin{array}{c}\text { KAWASAN } \\
1\end{array}$ & $\begin{array}{l}\text { Nagoya, Jodoh, Baloi, Batam Centre, Sei Panas, Bengkong, Batu Ampar, } \\
\text { Muka Kuning, sepanjang jalan muka kuning s/d simpang Base Camp, } \\
\text { Batu Merah, Bandara dan Pelabuhan Laut }\end{array}$ \\
\hline 2 & $\begin{array}{c}\text { KAWASAN } \\
2\end{array}$ & $\begin{array}{l}\text { Sagulung, Batu Aji (diluar sepanjang jalan muka kuning s/d simpang } \\
\text { Base Camp), Sei Harapan, Sekupang, Tanjung Uncang, Tanjung Riau }\end{array}$ \\
\hline 3 & $\begin{array}{c}\text { KAWASAN } \\
3\end{array}$ & $\begin{array}{l}\text { Tanjung Piayu, Batu Besar, Nongsa, Kabil/ Telaga Punggur, Belakang } \\
\text { Padang, Galang. } \\
\text { Seluruh Kawasan diluar/ tidak termasuk kawasan A dan B }\end{array}$ \\
\hline
\end{tabular}

Sumber: Peraturan Walikota Batam Nomor 24 Tahun 2011

\section{Pendapatan Asli Daerah (PAD)}

Pajak Daerah menurut Mardiasmo (2013:12) adalah iuran yang dilakukan oleh orang pribadi atau badan kepada daerah tanpa imbalan langsung yang seimbang, yang dapat dipaksakan berdasarkan peraturan perundang-undangan yang berlaku, yang digunakan untuk membiyai penyelenggaraan pemerintah daerah. Pajak Daerah merupakan pajak yang ditetapkan oleh pemerintah daerah dengan peraturan daerah (Perda) yang wewenang pemungutannya dilaksanakan oleh pemerintah daerah dalam melaksanakan penyelenggaraan pemerintah dan pembangunan daerah.

Dasar hukum pemungutan Pajak Daerah dan Retribusi Daerah adalah Undang-undang Nomor 18 Tahu 1997 tentang Pajak Daerah dan Retribusi Daerah Sebagaimana telah diatur terakhir dengan Undang-undang Nomor 28 Tahun 2009. Menurut Undang-undang Nomor 28 
Tahun 2009, Peraturan Daerah Kota Batam Nomor 5 Tahun 2011 tentang Pajak Daerah. Yang dimaksud dengan Pajak Daerah yang selanjutnya disebut pajak adalah kontribusi wajib kepada daerah yang terutang oleh orang pribadi atau badan yang bersifat memaksa berdasarkan Undang-undang, dengan baik memdapatkan imbalan secara langsung dan digunakan untuk keperluan daerah bagi sebesar-sebesarnya kemakmuran rakyat.

Adapun jenis-jenis pajak daerah yaitu: Pajak Hotel; Pajak Restoran; Pajak Hiburan; Pajak Reklame; Pajak Penerangan Jalan; Pajak Pengambilan Bahan Galian Golongan C; Pajak Parkir; Pajak Air Tanah; Pajak Sarang Burung Walet; Pajak Bumi dan Bangunan Perdesaan dan Perkotaan; dan Bea Perolehan Hak atas Tanah dan Bangunan.

Menurut Darise (2008: 33) Pendapatan daerah meliputi semua penerimaan uang melalui rekening kas umum daerah, yang menambah ekuitas dana lancar, yang merupakan hak daerah dalam satu tahun anggaran yang tidak perlu dibayar kembali oleh daerah. Pendapatan daerah terdiri atas:

1. Pendapatan asli daerah

2. Dana pertimbangan

3. Lain-lain pendapatan daerah yang asli

Menurut Darise (2008: 33) Pendapatan Asli Daerah (PAD) adalah pendapatan yang diperoleh daerah yang dipungut berdasarkan peraturan daerah sesuai dengan peraturan perundangundangan. Sebagaimana diatur dalam pasal 6 undang-undang nomor 33 tahun 2004, tentang perimbangan keuangan antara pemerintah pusat dan pemerintah daerah menyatakan sumbersumber PAD terdiri dari:

1. Pajak daerah

2. Retribusi daerah

3. Hasil pengelolaan kekayaan daerah yang dipisahkan

4. Lain-lain Pendapatan Asli Daerah (PAD) yang sah

Pendapatan Asli Daerah (PAD) sebagai salah satu sumber penerimaan daerah yang berasal dari dalam daerah yang bersangkutan harus ditingkatkan seoptimal mungkin dalam rangka mewujudkan semangat kemandirian lokal. Mandiri diartikan sebagai semangat dan tekad yang kuat untuk membangun daerahnya sendiri dengan tidak semata-mata menggantungkan pada fasilitas atau faktor yang berasal dari luar (Adisasmita, 2011: 2)

Pengertian Pendapatan Asli Daerah menurut Undang-undang Nomor 28 Tahun 2009 yaitu sumber keuangan daerah yang digali dari wilayah daerah yang bersangkutan yang terdiri dari hasil pajak daerah, hasil retribusi daerah, hasil pengelolaan kekayaan daerah yang dipisahkan dan lain-lain pendapatan asli daerah yang sah. Pendapatan Daerah adalah semua hak daerah yang diakui sebagai nilai kekayaan bersih dalam periode anggaran tertentu. Sesuai dengan Undang-undang Nomor 32 Tahun 2004 Tentang Pemerintah Daerah, bahwa daerah itu sendiri yaitu pendapatan asli daerah serta lain-lain pendapatan yang sah.

\section{Kerangka Pemikiran}

(Sugiyono, 2013: 60) mengemukakan bahwa seorang peneliti harus menguasai teori-teori ilmiah sebagai dasar menyusun kerangka pemikiran yang membuahkan hasil hipotesis. Sedangkan Kerangka pemikiran ialah penjelasan sementara terhadap gejala yang menjadi objek permasalah.

Maka dari itu dapat dijelaskan bahwa objek permasalahan yang di angkat dalam penelitian ini ialah "Analisis Kinerja Pemungutan Dan Retribusi Pajak Reklame Terhadap Pendapatan Asli Daerah (PAD) Kota Batam”. Konsep yang telah dijelaskan tersebut dapat digambarkan seperti di bawah ini : 


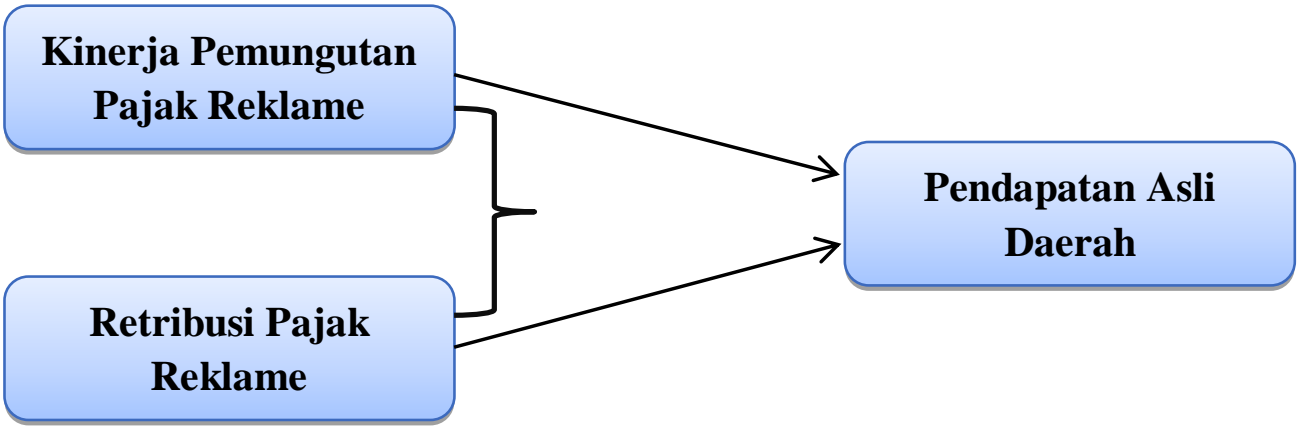

Gambar 1. Kerangka Pemikiran hipotesis:

Berdasarkan kerangka pemikiran dalam penelitian ini, maka penulis mengajukan

$\mathrm{H}_{1}$ : Kinerja Pemungutan berpengaruh signifikan terhadap Pendapatan Asli Daerah (PAD).

$\mathrm{H}_{2}$ : Retribusi Pungutan Pajak Reklame berpengaruh signifikan terhadap Pendapatan Asli Daerah (PAD).

$\mathrm{H}_{3}$ : Kinerja Pemungutan dan Retribusi Pungutan Pajak Reklame berpengaruh signifikan terhadap Pendapatan Asli Daerah (PAD).

\section{METODE}

Penelitian adalah suatu proses mencari sesuatu secara sistematik dalam waktu yang lama dengan menggunakan metode ilmiah serta aturan-aturan yang berlaku. Untuk dapat menghasilkan suatu penelitian yang baik, maka peneliti bukan hanya mengetahui aturan permainan, tetapi juga harus mempunyai keterampilan-keterampilan dalam melaksanakan penelitian. Untuk menerapkan metode ilmiah dalam praktek penelitian, maka diperlukan suatu desain penelitian, yang sesuai dengan kondisi, seimbang dengan penelitian yang dikerjakan(Nazir, 2014: 70).

Desain penelitian merupakan suatu rencana kerja yang terstruktur dalam hal hubungan hubungan antar variabel secara komprehensif, sedemkian rupa agar hasil risetnya dapat memberikan jawaban atas pertanyaan - pertanyaan riset. Dalam rencana tersebut mencakup hal - hal yang akan dilakukan periset mulai dari membuat hipotesis dan implikasinya secara operasional sampai pada analisis terakhir (Umar, 2010: 5)

Proses perencanaan penelitian dimulai dari identifikasi, pemilihan serta rumusan masalah, sampai dengan perumusan hipotesis serta kaitannya dengan teori dan kepustakaan yang ada (Nazir, 2014: 70-71). Sampel penelitian Laporan keuangan yang berupa target penerimaan,realisasi penerimaan pajak reklame dan penerimaan Pendapatan Asli Daerah Kota Batam tahun 2011-2015. Metode analisis yang digunakan adalah persamaan Regersi Linear Berganda $Y=a+b_{1} X_{1}+b_{2} X_{2}+\varepsilon$.

Keterangan:

$$
\begin{array}{ll}
\mathrm{Y} & =\text { Pendapatan Asli Daerah }(\mathrm{PAD}) \\
\mathrm{A} & =\text { Konstanta persamaan regresi } \\
\mathrm{b}_{1}, \mathrm{~b}_{2}, \mathrm{~b}_{3} & =\text { Koefisien regresi } \\
\mathrm{X}_{1} & =\text { Kinerja Pemungutan } \\
\mathrm{X}_{2} & =\text { Retribusi Pungutan Pajak Reklame } \\
\mathrm{e} & =\text { Error/ epsilon (faktor lain yang mempengaruhi) }
\end{array}
$$




\section{HASIL DAN PEMBAHASAN}

A. Hasil Uji Asumsi Klasik

1). Hasil Uji Multikolinieritas

Hasil pengujian multikolinieritas dapat dilihat pada tabel berikut:

Tabel 1. Hasil Uji Multikolinieritas

\begin{tabular}{|c|r|r|l|}
\hline \multirow{2}{*}{ Variabel } & \multicolumn{2}{|c|}{ Collinearity Statistics } & \multirow{2}{*}{ Kesimpulan } \\
\cline { 2 - 3 } & Tolerance & VIF & \\
\hline $\mathrm{X}_{1}$ & $\mathbf{0 . 5 7 1}$ & $\mathbf{1 . 7 5 0}$ & Tidak Terjadi Multikolinieritas \\
$\mathrm{X}_{2}$ & $\mathbf{0 . 5 7 1}$ & $\mathbf{1 . 7 5 0}$ & Tidak Terjadi Multikolinieritas \\
\hline
\end{tabular}

Berdasarkan hasil pengujian multikolinearitas semua variabel diatas memiliki nilai VIF dibawah angka 10 dan nilai tolerance lebih dari 0.1. Hal ini menunjukkan tidak terjadi multikolinieritas atau hubungan antar variabel independen dalam model regresi tersebut.

\section{2). Hasil Uji Normalitas} berikut:

Hasil pengujian asumsi normalitas dalam penelitian ini dapat dilihat pada gambar sebagai

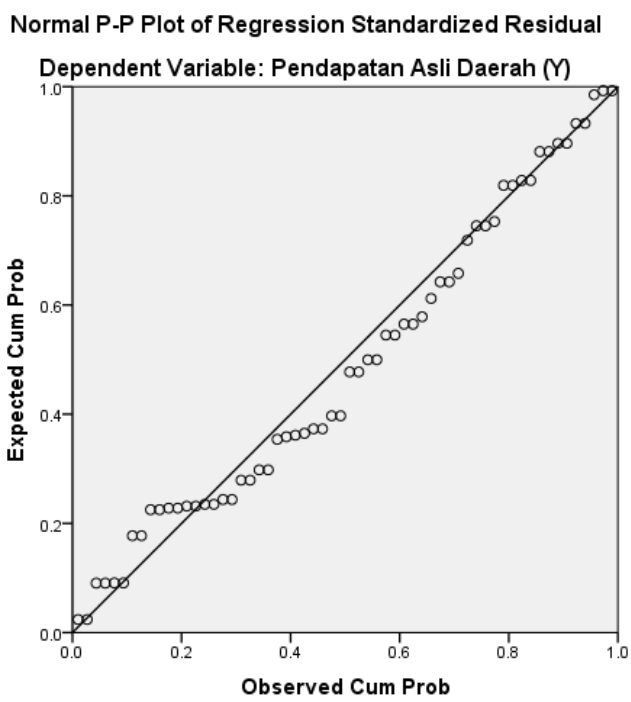

Gambar 2. Hasil Uji Normalitas

Dari hasil pengujian normalitas di atas, menunjukkan titik-titik menyebar di sekitar garis diagonal untuk variabel dependen Pendapatan Asli Daerah (PAD). Penyebaran tersebut mengikuti arah garis diagonal. Hal ini menunjukkan bahwa data tersebar dengan normal dan model regresi tersebut layak untuk dipakai.

3). Hasil Uji Heteroskedastisitas

Hasil pengujian heteroskedastisitas dapat dilihat pada gambar sebagai berikut:

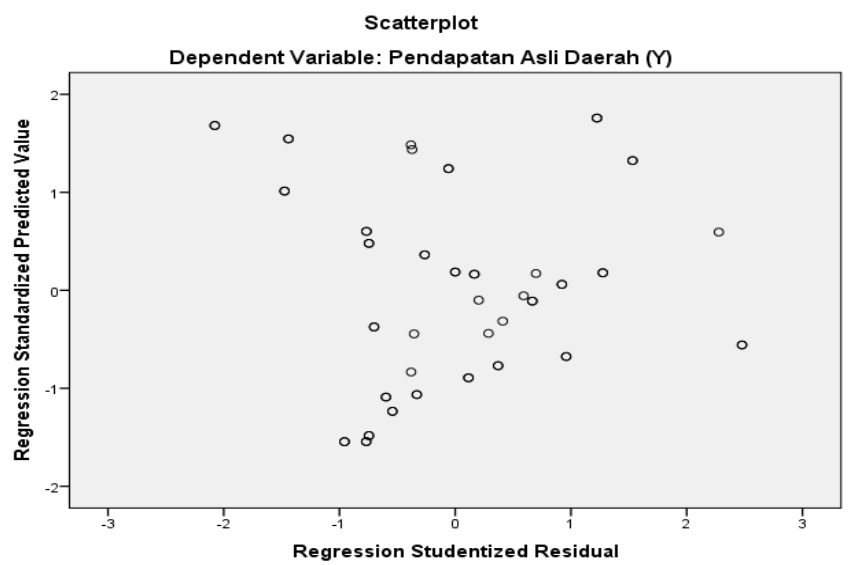


Gambar 3 Hasil Uji Heteroskedastisitas

Dari gambar di atas, dapat dilihat bahwa titik-titik menyebar di atas dan dibawah angka nol pada sumbu $\mathrm{Y}$ dan tidak membentuk pola yang jelas sehingga tidak terjadi masalah heteroskedastisitas.

\section{B. Hasil Uji Hipotesis}

1). Analisis Regresi Berganda (Multiple Regression Linear)

Untuk uji hipotesis ini digunakan analisis regresi berganda (Multiple Regression Linear).

Tabel 2. Hasil Uji Regrsi Linier Berganda

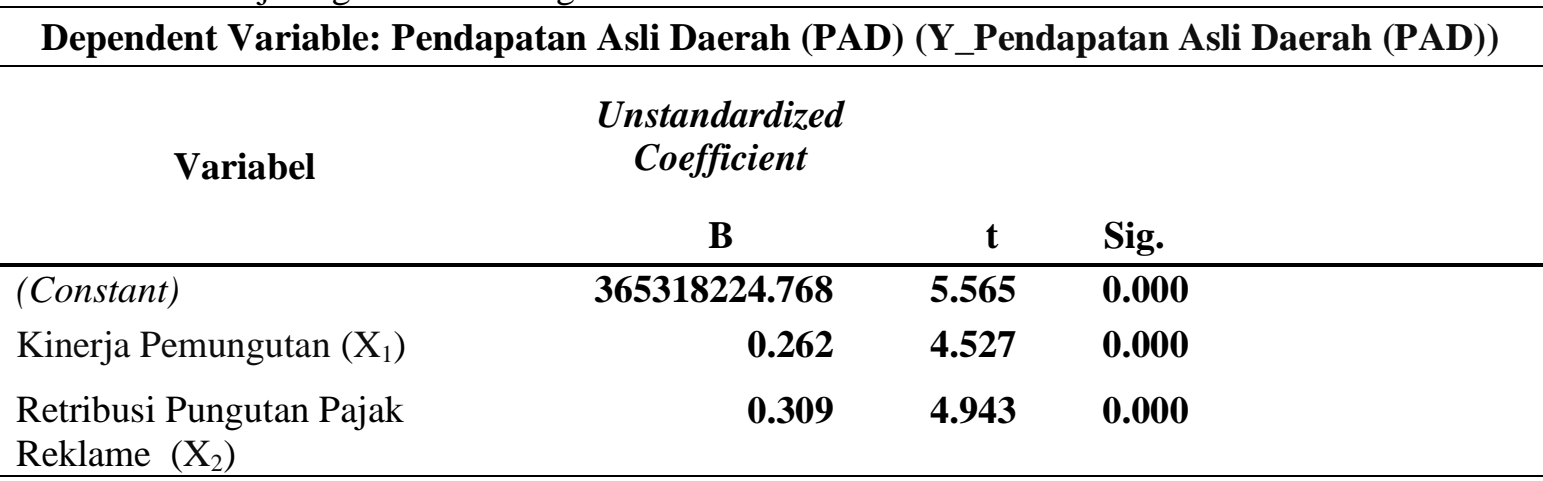

Persamaan regresi dan hasil pengujian hipotesis adalah sebagai berikut:

$$
\mathrm{Y}=365318224.768+0.262 \mathrm{X}_{1}+0.309 \mathrm{X}_{2}+e
$$

Dari persamaan diatas dapat disimpulkan bahwa setiap 1 skor Kinerja Pemungutan $\left(\mathrm{X}_{1}\right)$ bertambah dengan satu-satuan maka akan mempengaruhi Y_Pendapatan Asli Daerah (PAD) sebesar 0.262 (26.20\%), dan setiap 1 skor Retribusi Pungutan Pajak Reklame $\left(\mathrm{X}_{2}\right)$ bertambah maka akan mempengaruhi Y_Pendapatan Asli Daerah (PAD) sebesar 0.309 (30.90\%) selebihnya di pengaruhui oleh faktor lain.

\section{2). Hasil Uji t}

Hasil uji t dapat dilihat pada tabel berikut:

Tabel 3. Hasil Uji t

\begin{tabular}{lrrrr}
\multicolumn{1}{c}{ Dependent Variable: Pendapatan Asli Daerah (PAD) } & (Y_Pendapatan Asli Daerah (PAD)) \\
\hline \multicolumn{1}{c}{ Variabel } & $\begin{array}{c}\text { Unstandardized } \\
\text { Coefficient }\end{array}$ & & & Kesimpulan \\
& B & t & Sig. & \\
\hline (Constant) & $\mathbf{3 6 5 3 1 8 2 2 4 . 7 6 8}$ & $\mathbf{5 . 5 6 5}$ & $\mathbf{0 . 0 0 0}$ & Signifikan \\
Kinerja Pemungutan $\left(\mathrm{X}_{1}\right)$ & $\mathbf{0 . 2 6 2}$ & $\mathbf{4 . 5 2 7}$ & $\mathbf{0 . 0 0 0}$ & Signifikan \\
Retribusi Pungutan Pajak & $\mathbf{0 . 3 0 9}$ & $\mathbf{4 . 9 4 3}$ & $\mathbf{0 . 0 0 0}$ & Signifikan \\
Reklame $\left(\mathrm{X}_{2}\right)$ & & & & \\
\hline
\end{tabular}

\section{a. Hasil Pengujian Kinerja Pemungutan $\left(\mathrm{X}_{1}\right)$ Terhadap Pendapatan Asli Daerah (PAD)} (Y_Pendapatan Asli Daerah (PAD))

Hasil dari terhadap variabel dependen Pendapatan Asli Daerah (PAD) yang diukur dengan Y_Pendapatan Asli Daerah (PAD) sebesar 0.000 dan nilai koefisien sebesar 0.262 (83.2\%). Nilai probabilitas yang kurang dari 0.05 menunjukkan bahwa Kinerja Pemungutan berpengaruh signifikTabel 4.7 di atas menunjukkan bahwa nilai probalitas Kinerja Pemungutan terhadap Pendapatan Asli Daerah (PAD). Nilai koefisien 0.262 (26.2\%) menunjukkan arah pengaruh positif dari Kinerja Pemungutan.

Kinerja Pemungutan berpengaruh signifikan terhadap Pendapatan Asli Daerah (PAD). Hal ini mungkin disebabkan Kinerja Pemungutan pada setiap perusahaan nilai tidak tetap 
sehingga modal kerja perusahaan juga sering berubah sehingga Pendapatan Asli Daerah (PAD) juga sering mengalami perubahan.

b. Hasil Pengujian Retribusi Pungutan Pajak Reklame $\left(\mathbf{X}_{2}\right)$ Terhadap Pendapatan Asli

\section{Daerah (PAD) (Y_Pendapatan Asli Daerah (PAD))}

Hasil dari Tabel 4.7 di atas menunjukkan bahwa nilai probalitas Retribusi Pungutan Pajak Reklame terhadap variabel dependen Pendapatan Asli Daerah (PAD) yang diukur dengan Y_Pendapatan Asli Daerah (PAD) sebesar 0.000 dan nilai koefisien sebesar 0.309 (30.9\%). Nilai probabilitas yang kurang dari 0.05 menunjukkan bahwa Retribusi Pungutan Pajak Reklame berpengaruh signifikan terhadap Pendapatan Asli Daerah (PAD). Nilai koefisien 0.309 (57.8\%) menunjukkan arah pengaruh positif dari Retribusi Pungutan Pajak Reklame.

Retribusi Pungutan Pajak Reklame berpengaruh signifikan terhadap Pendapatan Asli Daerah (PAD). Hal ini mungkin disebabkan rata-rata perusahaan sampel melaksanakan penagihan piutangnya dengan lancar sehingga modal kerja perusahaan meningkat dan meningkatkan Pendapatan Asli Daerah (PAD).

\section{3). Hasil Uji F}

Hasil pengujian $\mathrm{F}$ dapat dilihat pada tabel berikut:

Tabel 4. Hasil Uji F

\begin{tabular}{cccc}
\hline Variabel Dependen & F & Sig. & Kesimpulan \\
\hline $\begin{array}{c}\text { Y_Pendapatan Asli Daerah } \\
(\text { PAD })\end{array}$ & $\mathbf{6 4 . 9 5 4}$ & $\mathbf{0 . 0 0 0}$ & Signifikan \\
\hline
\end{tabular}

c. Hasil Pengujian Variabel Kinerja Pemungutan $\left(X_{1}\right)$ dan Retribusi Pungutan Pajak Reklame $\left(\mathbf{X}_{2}\right)$ secara simultan Terhadap Pendapatan Asli Daerah (PAD) (Y_Pendapatan Asli Daerah (PAD))

Berdasarkan hasil uji $\mathrm{F}$, nilai $\mathrm{F}$ yang diperoleh untuk variabel dependen Pendapatan Asli Daerah (PAD) sebesar 64.954 dengan nilai probabilitasnya 0.000. Karena nilai signifikansi kurang dari 0.05 maka dapat disimpulkan bahwa model regresi tersebut dapat digunakan untuk memprediksi Pendapatan Asli Daerah (PAD).

\section{4). Hasil Uji Koefisien Determinasi $\left(\mathbf{R}^{2}\right)$}

Tabel 5. Hasil Uji Koefisien Determinasi $\left(\mathrm{R}^{2}\right)$

\begin{tabular}{cccc}
\hline Variabel Dependen & $\boldsymbol{R}$ & $\boldsymbol{R}$ Square & Adjusted $\boldsymbol{R}$ Square \\
\hline Y_Pendapatan Asli & & & \\
Daerah (PAD) & $\mathbf{8 3 . 4 0 \%}$ & $\mathbf{6 9 . 5 0 \%}$ & $\mathbf{6 8 . 4 0 \%}$ \\
\hline
\end{tabular}

Hasil pengujian menunjukkan bahwa nilai Adjusted $R$ Square $\left(\mathrm{R}^{2}\right)$ untuk model penelitian penulis adalah sebesar $\mathbf{6 8 . 4 0 \%}$. Nilai Adjusted $R$ Square $\left(\mathrm{R}^{2}\right)$ sebesar $\mathbf{6 8 . 4 0 \%}$ ini mengindikasikan bahwa variabel independen dapat menjelaskan variabel dependen sebesar $\mathbf{6 8 . 4 0 \%}$, sedangkan $\mathbf{3 1 . 6 0 \%}$ lainnya dijelaskan oleh faktor lain yang tidak terdapat dalam model.

\section{SIMPULAN}

Berdasarkan hasil penelitian pada bab-bab sebelumnya, menunjukkan bahwa:

1. Kinerja Pemungutan Pajak Reklame berpengaruh positif dan signifikan terhadap Pendapatan Asli Daerah di Kota Batam.

2. Pungutan Retribusi Pajak Reklame berpengaruh positif dan signifikan terhadap Pendapatan Asli Daerah di Kota Batam.

3. Kinerja Pemungutan Pajak Reklame dan Pungutan Retribusi Pajak Reklame secara bersama-sama memiliki pengaruh yang positif dan signifikan terhadap Pendapatan Asli Daerah di Kota Batam. 


\section{SARAN}

Adapun rekomendasi yang dapat disarankan penulis untuk penelitian selanjutnya adalah:

1. Perlu melakukan pendataan secara rutin terhadap objek pajak reklame yang sudah ada sehingga dapat diketahui potensi yang sebenarnya melalui data objek pajak tersebut. Selain itu proses penetapan target harusnya memperhatikan potensi yang sebenarnya sehingga DISPENDA Kota Batam akan terpacu untuk mencapai target tersebut dan dapat meningkatkan penerimaan pajak reklame.

2. Perlu melakukan sosialisasi secara rutin terhadap wajib pajak guna meningkatkan kesadaran wajib pajak terhadap kewajibannya dalam hal ketaatan pembayaran pajak tepat waktu dan tepat jumlah. DISPENDA juga diharap mampu memberikan sanksi tegas terhadap wajib pajak yang kurang taat dalam melaksanakan kewajibannya.

3. Diharapkan pada penelitian berikutnya yang akan membahas topik yang sama, agar memperluas ruang lingkup penelitiannya.

\section{DAFTAR PUSTAKA}

Fidel. (2010). Pajak Penghasilan Carofin Publising, Jakarta.

Ghozali, Imam. (2011). Aplikasi Analisis Multivariate Dengan Program IBM SPSS 19. (Edisi

Kelima.) Semarang: Universitas Diponegoro.

Kuswanto, Hedy. (2012). Analisis Faktor-Faktor Yang Mempengaruhi Kinerja Sistem Informasi Akuntansi Pada PT. BPR Weleri Makmur Jawa Tengah. (Versi Elektronik). Jurnal STIE Dharmaputra. Diperoleh 05 Oktober 2012, dari http:// ejournal.stiedharmaputrasmg.ac.id.

Mardiasmo. (2013). Perpajakan Edisi Revisi, Andi Offset, Yogyakarta.

Nazir, Moh. (2014). Metode Penelitian. Cetakan Enam, Bogor: Penerbit Ghalia Indonesia.

Priyatno, Duwi. (2008). Mandiri Belajar SPSS - Bagi Mahasiswa dan Umum, Yogyakarta: Mediakom.

Sugiyono. (2014). Metode Penelitian Kuantitatif, Kualitatif, dan Kombinasi (Mixed. Methods). Bandung: Alfabeta.

Umar, Husein. (2010). Metode Penelitian Untuk Skripsi dan Tesis serta Bisnis. Edisi Kedua. Jakarta: Penerbit Raja Grafindo Persada.

Undang-undang Nomor 28 Tahun 2009 tentang Pajak Daerah dan Retribusi Daerah dan Peraturan Daerah Kota Batam Nomor 12 Tahun 2008 tentang pokok-pokok pengelolaan keuangan daerah, membawa paradigma baru dalam pengelolaan daerah.

Undang-undang Nomor 22 Tahun 1999 tentang Pemerintahan Daerah selanjutnya disingkat dengan sebutan UU No. 22/1999.

Undang-undang Nomor 18 Tahun 1987 tentang Pajak Daerah dan Retribusi Daerah selanjutnya disingkat dengan sebutan UU No. 18/1987.

Undang-undang Nomor 34 Tahun 2000 tentang Perubahan Atas Undang-undang Nomor 18 Tahun 1987 tentang Pajak Daerah dan Retribusi Daerah, selanjutnya disingkat dengan sebutan UU No. 34/2000.

Waluyo. B Ilyas, Wirawan. (2011). Perpajakan Indonesia, Buku 1 Edisi 10. Salemba Empat. Jakarta.

Wibowo, Agung Edy. (2012). Aplikasi Praktis SPSS Dalam Penelitian. Yogyakarta: Gava Media. 